\title{
Anthropometric study of nasal index in Hausa ethnic population of northwestern Nigeria
}

\author{
Ibrahim Mohammed, ,ab Tahmineh Mokhtari, ${ }^{,, d}$ Sahar ljaz, ${ }^{a, b}$ Akanji Omotosho D, ${ }^{a, b}$ Abdullahi Abubakar Ngaski, \\ Maryam Milanifard, a and Gholamreza Hassanzadeh ${ }^{\mathrm{a}}$
}

\author{
aDepartment of Anatomy, School of Medicine, Tehran University of Medical Sciences, Tehran, Iran. \\ bDepartment of Anatomy, School of Medicine, International Campus, Tehran University of Medical Sciences, Tehran, Iran. \\ 'Research Center of Nervous System Stem Cells, Department of Anatomy, School of Medicine, Semnan University of Medical Sciences, Semnan, Iran. \\ dDepartment of Anatomy, School of Medicine, Semnan University of Medical Sciences, Semnan, Iran. \\ eDepartment of Chemical Pathology, Faculty of Medical Laboratory Sciences, Usmanu Danfodiyo University, Sokoto, Nigeria. \\ Correspondence to Gholamreza Hassanzadeh (email: hassanzadeh@tums.ac.ir). \\ (Submitted: 14 September 2017 - Revised version received: 27 October 2017 - Accepted: 02 November 2017 - Published online: 26 March 2018)
}

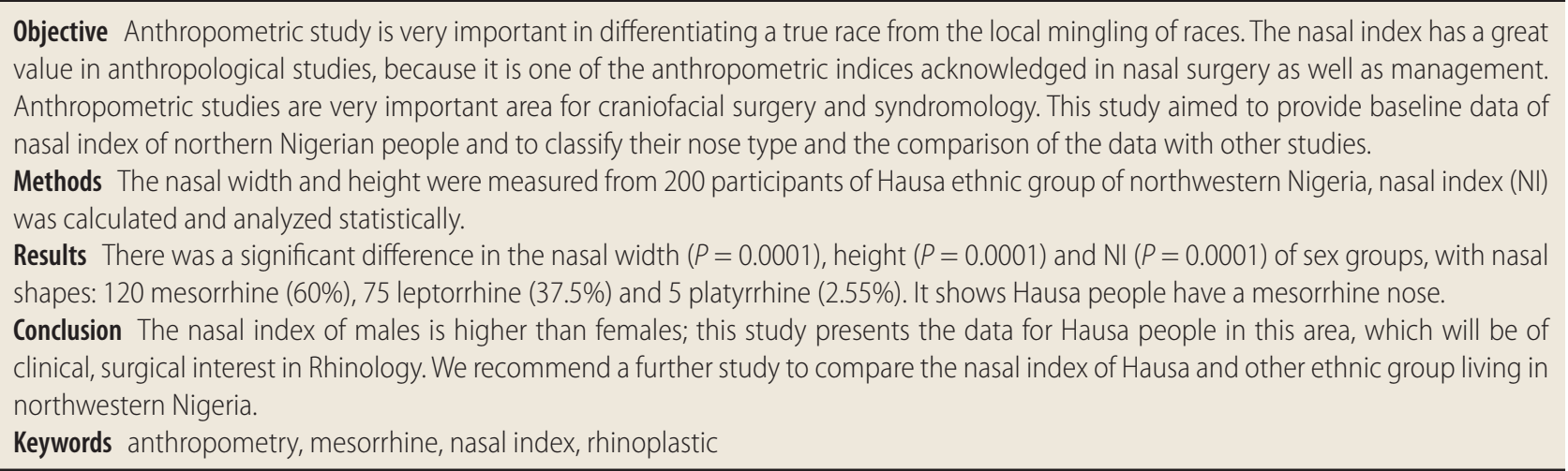

\section{Introduction}

Anthropometric studies are scientific methods and techniques for displaying different measurement and observation on the human being as well as skeleton. Anthropometric studies are very important area for craniofacial surgery and syndromology. ${ }^{1}$ Variation is the great phenomena existing among human being, and it is related to different factors such as mutation and natural selection. Different researches show the advantage of anthropometric measurement as a tool for studying the variation in human population and very important in forensic science for crime investigation. ${ }^{2}$ In the 20 th century, the relevance of anthropometry to the study of different races was substituted by different sophisticated methods for determining racial variations. Nowadays, anthropometry has got recognition in medical sciences particularly forensic medicine. $^{2}$

Nasal anthropometry is a study that deals with the measurements of the proportion, size as well as shape of nose of the human being. ${ }^{3}$ The study of nasal anthropology is very important in forensics as well as physical anthropology as one of the techniques used in the determination of different races, ethnicity as well as gender of an individual. ${ }^{4}$ Some studies documented that bioenvironmental, geographical as well as biological factors, ethnicity, sex and age have influence in body dimensions especially in the head and neck region. ${ }^{5-7}$ In anthropology and forensic medicine, the knowledge of nasal index (NI) is relevant in distinguishing the race, ethnicity and sex of individuals whose identity is not known. ${ }^{2,8} \mathrm{NI}$ is also useful in the analysis and classification of fossil remains as well as the study of living population. ${ }^{9}$
In clinical practice, NI is useful in rhinoplastic surgery (plastic surgery of the nose) as nasal analysis is the first step. A rhinoplastic surgeon takes to change the size or shape of the nose for a desired aesthetic effect. Also, nasal analysis of a particular ethnic group can help the rhinoplastic surgeon change the shape of nose of a patient without compromising the patient's desire to maintain his cosmetic status. ${ }^{10}$ NI measurement in healthy individuals is also useful for dysmorphologists in the early diagnosis of some dysmorphic syndromes like cleft lip and palate which are associated with nose disorders. ${ }^{4}$

The NI is determined as the percentage of the width in relation to the height of the nose. While on skeleton, the height is measured from the nasion (where the internasal suture touches the frontal bone) to a level just at the bottom of the nasal spine. The width on the skull is the maximum distance on the nasal sinuses. On living human, the height is from nasion to the subnasal (where the nasal septum touches the upper lip). The nasal width on living human is the highest distance between the two nasal wings or two alae in anatomical position. Usually, the NI on living human and the NI on skeleton never correspond to each other. ${ }^{11}$

A nose is referred to leptorrhine if the NI is $69.9 \%$ or less (long and narrow nose), mesorrhine nose if the NI is between $70 \%$ and $84.9 \%$ (medium) and platyrrhine nose if the NI is above $85 \%$ (broad nose). ${ }^{8,12}$ The platyrrhine nose generally has a very prominent ala lobule with a complete and well-rounded nasal tip. The mesorrhine nose has a small prominent lobule with more clear nasal tip and the leptorrhine nose has very small prominent ala lobule with well-defined nasal tip. ${ }^{13}$ 
Majority of Caucasians have the leptorrhine type of nose characterized as long and narrow. The Indo-Aryan is like European people with fine nose. ${ }^{14}$ Jingpo people of China have mesorrhine nose..$^{15}$ Indo-African ${ }^{14}$ as well as Afro-American ${ }^{16}$ possessed platyrrhine nose. Risley described that the NI of African descent has platyrrhine nose. Sarka ${ }^{11}$ also revealed that the nose of Australian aborigines varies from that of Negro by more intensely depressed root.

Facial anthropometry is one of the most important aspects used in reconstructive surgery, forensic investigation as well as genetic counseling. ${ }^{10,17,18}$ The external nose is a part of the human nose that protrudes anteriorly from the face. ${ }^{19}$ The shape of the external nose is inconsistent, ${ }^{20}$ and is related to ethmoid bone as well as septum, which is made up of cartilage and separate nostrils apart.

The aim of the study was to provide baseline data of certain nasal anthropometric measurements for male and female of northern Nigerian people and to classify their nose type and the comparison of the data with other studies, so that it would be further useful as an essential tool to the researchers, clinicians, rhinoplastic and facial reconstructive surgeons and forensic experts related to this field. The results from this study will also add to the pool of the anthropological data that may be used as a reference by other health practitioners' especially in Nigeria and worldwide.

\section{Materials and Methods}

On the basis of nasal height and breadth index, Martin and Sallar21 categorized noses (Table 1). This study is a cross-sectional study, conducted in northwestern part of Nigeria on 200 volunteered participants (100 males, 100 females) adult individuals. The age range of the participant was $16-60$ years. The volunteered participants of this study had no history of trauma, no physical deformities, no surgery of face or nose, and no history of cleft lip or palate. Nasal width and nasal height were measured using spreading venire caliper (manual) following standard method described by Martin and Saller.21 Nasal width was measured as a straight distance from right ala to left ala. Nasal height was measured as the distance from the nasion to the subnasale. The NI was calculated as follows:

$$
\mathrm{NI}=\text { nasal width/nasal height } \times 100 .^{22}
$$

\section{Statistical Analysis}

The data obtained were analyzed statistically. Basic descriptive statistics and independent sample $t$-test were carried out by computerized statistical analysis software-Statistical Package

\begin{tabular}{|c|c|c|c|}
\hline \multirow{2}{*}{ Categories } & \multirow{2}{*}{ Size of nose } & \multicolumn{2}{|c|}{ Nasal index } \\
\hline & & On living head & On skull \\
\hline Hyperleptorrhine & $\begin{array}{l}\text { Long narrow } \\
\text { nose }\end{array}$ & $40-54.9$ & - \\
\hline Leptorrhine & $\begin{array}{l}\text { Moderately } \\
\text { narrow nose }\end{array}$ & Less than 70 & Less than 47 \\
\hline Mesorrhine & $\begin{array}{l}\text { Moderate or } \\
\text { medium size }\end{array}$ & $70-84.9$ & $47-50.9$ \\
\hline Platyrrhine & $\begin{array}{l}\text { Moderately } \\
\text { wide nose }\end{array}$ & $85-99.9$ & $51-57.9$ \\
\hline Hyperplatyrrhine & $\begin{array}{l}\text { Very wide } \\
\text { nose }\end{array}$ & 100 or more & 58 or more \\
\hline
\end{tabular}

\begin{tabular}{lcccc}
\hline \multicolumn{5}{c}{ Table 2. Statistical analysis of nasal parameters } \\
\hline & Mean & SD $^{*}$ & Minimum & Maximum \\
\hline Nasal width (cm) & 3.91 & 0.42 & 3.01 & 5.37 \\
Nasal height (cm) & 5.45 & 0.47 & 4.2 & 6.65 \\
Nasal index & 71.99 & 7.17 & 54 & 91 \\
\hline
\end{tabular}

Table 3. Descriptive statistical analysis of nasal index of males and females

\begin{tabular}{lccccc}
\hline & Mean & SD $^{*}$ & Minimum & Maximum & P-value \\
\hline $\begin{array}{l}\text { Nasal width } \\
\text { (cm) in male }\end{array}$ & 4.13 & 0.38 & 3.15 & 5.37 & 0.0001 \\
$\begin{array}{l}\text { Nasal width } \\
\text { (cm) in female }\end{array}$ & 3.69 & 0.34 & 3.01 & 4.91 & \\
$\begin{array}{l}\text { Nasal height } \\
\text { (cm) in male }\end{array}$ & 5.59 & 0.38 & 4.61 & 6.55 & 0.0001 \\
$\begin{array}{l}\text { Nasal height } \\
\text { (cm) in female }\end{array}$ & 5.31 & 0.51 & 4.2 & 6.65 & \\
$\begin{array}{l}\text { Nasal index in } \\
\text { male }\end{array}$ & 74.08 & 6.92 & 56 & 89 & 0.0001 \\
$\begin{array}{l}\text { Nasal index in } \\
\text { female }\end{array}$ & 69.9 & 6.83 & 54 & 91 & \\
\hline
\end{tabular}

*Standard deviation.

Table 4. Frequency (percentage) of nose shapes of males and females

\begin{tabular}{lccc}
\hline & $\begin{array}{c}\text { Male } \\
\text { frequency (\%) }\end{array}$ & $\begin{array}{c}\text { Female } \\
\text { frequency (\%) }\end{array}$ & $\begin{array}{c}\text { Total } \\
\text { frequency (\%) }\end{array}$ \\
\hline Leptorrhine & $25(25)$ & $50(50)$ & $75(37.5)$ \\
Mesorrhine & $71(71)$ & $49(49)$ & $120(60)$ \\
Platyrrhine & $4(4)$ & $1(1)$ & $5(2.55)$ \\
\hline
\end{tabular}

for Social Sciences (SPSS-22) and Microsoft Excel Windows 2007 . The $P$-value of less than 0.05 was considered statistically significant.

\section{Results}

The results consisting of the statistical analysis with respect to the measurement of nasal variables such as nasal width, nasal heights as well as NI of males and females are shown in Tables $2-4$. In this study, 100 males (50\%) and 100 females (50\%) were evaluated for the NI. The descriptive analysis of data was shown in Table 1 . There was a significant difference in the nasal width $(P=0.0001)$, height $(P=0.0001)$ and NI $(P=0.0001)$ of sex groups as shown in Table 3. The nasal shapes were described according to the NI and its distribution in this study was as follows: 120 mesorrhine (60\%), 75 leptorrhine (37.5\%) and 5 platyrrhine $(2.55 \%)$ types. The distribution of nasal shapes in the sex groups was demonstrated in Table 4. The most nasal shape frequency was related to mesorrhine type in male group and equally leptorrhine and mesorrhine in female group.

\section{Discussion}

Nose is very important in racial origin. ${ }^{23}$ The NI plays a vital role in anthropology and is one among the clinical anthropometric 
parameters to be considered in nasal surgical and medical management. ${ }^{24,25} \mathrm{NI}$ is associated to regional and climatic variations. ${ }^{26}$ Many studies have shown the racial and ethnic differences in NI between different populations. ${ }^{27}$ Majority of Caucasians are leptorrhine with long and narrow nose and NI of 69.9 or less. The Indo-Aryan is as well similar to the European with fine nose. ${ }^{14}$ The Jingpo people of China are mesorrhine. ${ }^{15}$ Indo-African ${ }^{14}$ as well as Afro-American people have platyrrhine nose type. ${ }^{16}$

From the results of this study, the statistical analysis of nasal parameters shown in Table 1, shows the mean, standard deviation, minimum and maximum range of nasal parameters, nasal width, nasal height and NI. Comparing the current study with the study conducted by Jovanovic on the nasal parameters of Serbian population (Caucasians) with mean NI of $66.78,{ }^{28}$ it can be concluded that the Hausa people living in northwestern part of Nigeria had a higher mean $(\mathrm{NI}=71.99)$. This shows that there are differences in the nasal parameters among different ethnic groups and races.

There were differences between the nasal parameters of both men and women. This result did not corroborate with a study carried out by Eliakim-Ikechukwu on nasal indices and bi-alar angle between two ethnic groups Igbo and Yoruba in Nigeria, in which he found out that no significant difference in the nasal parameters between the two ethnic groups. ${ }^{3}$ However, this present study is in conformity with the study carried out by Eliakim-Ikechukwu on nasal parameters of Ibibio and Yakurr ethnic groups in south-southern part of Nigeria as there was significant difference in the nasal parameters of the two ethnic groups. ${ }^{29}$ Also, a study conducted by Anas and Saleh revealed that anthropometric comparison of nasal indices among Hausa and Yoruba ethnic groups living in Kano State, northern part of Nigeria there was significant difference in nasal indices among the two ethnic groups. ${ }^{30}$ This result corroborates with the present study. Some previous studies revealed that the mean, median, minimal and maximal width, height and the NI in males are higher than the females and there was significant difference. ${ }^{31,32}$ These are in line with the current study. NI of the Hausa ethnic group living in northwestern Nigeria, males were identified with mesorrhine type of nose, while females with leptorrhine and mesorrhine type of nose, this is not in conformity with the previous studies carried out by Risley ${ }^{33}$ in which he revealed that African people has a platyrrhine type of nose. Another study conducted by Oladipo reported platyrrhine nose type in Igbo, Yoruba and Ijaw ethnic groups of southern part of Nigeria. ${ }^{7}$ Esomonu ${ }^{4}$ reported a platyrrhine type of nose among Bekwaras ethnic group in Cross River state Nigeria. Nevertheless, a few studies have revealed mesorrhine type of nose in some ethnic groups in Nigeria. Research conducted by Oladipo identified a mesorrhine nose type for Andoni ethnic group of Rivers State in Nigeria, ${ }^{34}$ mesorrhine type in Ikwerre males, ${ }^{35}$ Ibibio females and Yakurr males of south-southern part of Nigeria, ${ }^{29}$ it was also reported that mesorrhine type in Hausa people living in northern part of
Nigeria. ${ }^{30}$ Variations in NI occur among different ethnic groups; variation can be as a result of warmer climate with higher temperature in northern part of Nigeria ${ }^{36}$ compared to southern part of Nigeria. ${ }^{37}$

The classification of nose into different categories is a function of NI, in anthropology as it is applied in differentiating racial and ethnic variations. ${ }^{8,38}$ The NI as well shows sexual dimorphism ${ }^{39}$ that is why it is very important in forensic science particularly in gender differentiation. ${ }^{15}$ The shape of nose of the African people, when compared to other races counterparts, are said to be affected by the climatic and environmental conditions. ${ }^{40}$ The broader nose of the African populations might be due to natural selection that affects their warm moist environmental condition. ${ }^{41}$ The current study reported the NI of Hausa ethnic group living in northwestern Nigeria males $71 \%$ and females $50 \%$. The male NI was higher than the female NI. This is in conformity with research conducted by Oladipo et al., ${ }^{17}$ who reported the males from Igbo, Ijaw as well as Yoruba ethnic groups in southern part of Nigeria have higher NI than their female counterpart. Also, another report by Oladipo et al., ${ }^{34}$ revealed that there is a sexual dimorphism in the NI of Itsekiris and Urhobos of Nigeria, in which males reported to have higher NI compared to females. ${ }^{34}$

Results from the present study reported that Hausa ethnic group was found to be mesorrhine similar to oriental nose. ${ }^{42,43}$ Moreover, Negros have been reported as platyrrhine, which is not in conformity with the result obtained from this study and some previous studies amongst Negros. ${ }^{42}$ This shows that not all Negros are platyrrhine it might be due to interethnic genetic differences have more effect than climatic differences.

\section{Conclusion}

This present study determined the nasal index of males and females of Hausa ethnic group of northwestern Nigeria. The result from this study shows Hausa people have a mesorrhine type of nose. The nasal index of males is significantly higher than females, which confirmed the existence of sexual difference in nasal parameters possibly due to genetic, hormonal, nutrition and other related factors. There is no specific data for the nasal index of Hausa people in northwestern Nigeria; this study presents for the first time the nasal parameters for Hausa people in this area, thus providing a useful baseline and an anthropometric data that will be of clinical and surgical interest in Rhinology in this part of the world. We recommend a further study to compare the nasal index of Hausa and other ethnic group living in northwestern Nigeria.

\section{Acknowledgments}

The authors would like to thank staffs and students of Faculty of Medical Laboratory Sciences, Usmanu Danfodiyo University Sokoto, Nigeria. We would also like to thank the Anatomy Department of School of Medicine, Tehran University of Medical Sciences, Iran, for the success of this research. 


\section{References}

1. Choudhary A, Chowdhary DS. Comparative anthropometric study of nasal parameters between two ethnic groups of Rajasthan state. Int J Med Public Health. 2012;2:46.

2. Oladipo G, Udoaka A, Afolabi E, Bob-Manuel I. Nasal parameters of Itsekiris and Urhobos of Nigeria. Int J Biol Anthropol. 2008;3:1-5.

3. Eliakim-Ikechukwu C, Bassey T, Ihentuge C. Study of the nasal indices and bialar angle of the Ibo and Yoruba ethnic groups of Nigeria. J Biol Agric Healthcare. 2012;2:149-152.

4. Esomonu UG, Ude RA, Lukpata PU, Nandi EM. Anthropometric study of the nasal index of Bekwara ethnic group of Cross River state, Nigeria. Int Res J Appl Basic Sci. 2013;5:1262-1265.

5. Satija A, Kaushal S, Gopichand PV, Chhabra U. Study of relationship between facial index and gestational age in normal newborns. Nepal Med Coll J. 2010;12:133-136.

6. Bayat PD, Ghanbari A. The evaluation of craniofacial dimensions in female Arak newborns (central Iran) in comparison with other Iranian racial subgroups. Eur J Anat. 2013;13:77-82.

7. Hassanzadeh G, Sadr M, Alaghbandha N, Dehbashipour A, Abbas MA, Heydar Zeidi O. Anthropometric characteristics of craniums in residents of Qazvin, Iran and Dera Ghazi Khan, Pakistan: a comparative study. Anat Sci J. 2013;10:43-49.

8. Porter JP, Olson KL. Analysis of the African American female nose. Plast Reconstr Surg. 2003;111:627-628.

9. Alex FR, Steven B, Timothy GL. Human body composition, 4th ed.; Human Kinetics Publishers, 1996; pp. 167-172.

10. Olotu JE, Eroje A, Oladipo GS, Ezon-Ebidor E. Anthropometric study of the facial and nasal length of adult lgbo ethnic group in Nigeria. Int J Biol Anthropol. 2009;2:10-15.

11. Sarka J. Important Criteria for Racial Identification. Biology. The next Generation Library 2014.

12. Willams P, Dyson M, Dussak, JE, Bannister LH, Berry MM, Collins P, et al. Skeletal System. Gray's Anatomy, 3rd ed.; Churchill Livingstone: Edinburgh, 1995; pp. 609-612.

13. Jimoh RO, Alabi SB, Kayode AS, Salihu AM, Ogidi OD. Rhinometry: spectrum of nasal profile among Nigerian Africans. Braz J Otorhinolaryngol. 2011;77:589-593.

14. Sparks CZ, Jantz RL. A reassessment of human cranial plasticity: Boas revisited. Proc Natl Acad Sci. 2002:99:14636-14639.

15. Xu B, Wang Y, Ma J, Li M, Xu L. A computer-aid study on the craniofacial features of Archang race in Yunnan province of China. West China Journal of Stomatology. 2011;19:394-396.

16. Ofodile FA, Bokhari F. The African American nose: Part II. Ann Plast Surg. 1995:34:123-129.

17. Oladipo GS, Olabiyi AO, Oremosu AA, Noronha CC. Nasal indices among major ethnic groups in Southern Nigeria. Sci Res Essay. 2007;2:20-22.

18. Krishan K. Estimation of stature from cephalo-facial anthropometry in north Indian population. Forensic Sci Int. 2008;181:52e1-52e6.

19. Sinnatamby CS. Last's Anatomy: Regional and Applied, 11th ed.; Churchill Livingstone: Edinburgh, 2006; p. 385

20. Standring S. Gray's Anatomy: The Anatomical Basic of Clinical Practice, 40th ed.; Elsevier: London, 2008; p. 547.

21. Martin R, Saller K. Lehrbuch der Anthropologie, 3rd ed.; Gustav Fischer Verlag: Stuttgart, 1957; p. 11.
22. Romo T, Abraham MT. The ethnic nose. Facial Plast Surg. 2003;19: 296-278.

23. Madison G. The Passing of the Great Race. Part 1. Language and Nationality, Chapter 2-4, 2004; p. 1-6.

24. Hansen B, Mygind N. How often do normal persons sneeze and blow the nose? Rhinology. 2002:40:407-426.

25. Zankl A, Eberie L, Schinzel A. Growth chart for nose length, nasal protrusion and philtrum length from birth to 97 years. Am J Med Genet. 2002;111: 388-391.

26. Farkas $L G$, Kolar IR, Munro IR. Abstract on the geography of the nose, a morfometric study. Aesthet Plast Surg. 1986;10:191-123.

27. Oladipio GS, Gwunireama IU, Asawa OD. Anthropometric comparison of nasal indices between the Igbos and Yorubas in Nigeria. Global J Med Res. 2006:5:37-40.

28. Jovanović J, Jeremić D, Jovanović B, Maja V, Sazdanović P, Maja S, et al. Nasal morphological characteristics of the Serbian population. Arch Biol Sci Belgrade. 2014;66(1):227-234

29. Eliakim-Ikechukwu C, Iro CM, Ihentuge CJ, Bassey TE. Nasal parameters of Ibibio and Yakurr ethnic groups of south-south Nigeria. J Pharm Biol Sci. 2013;5:23-26.

30. Anas IY, Saleh MS. Anthropometric comparison of nasal indices between Hausa and Yoruba ethnic groups in Nigeria. J Sci Res Rep. 2014;3: 437-444.

31. Zolbin MM, Hassanzadeh G, Mokhtari T, Arabkheradmand A, Hassanzadeh S. Anthropometric studies of nasal parameters of Qazvin residents, Iran. MOJ Anat Physiol. 2015:1:1-5.

32. Tahmasebi F, Khanehzad M, Madadi S, Hassanzadeh G. Anthropometric study of nasal parameters in Iranian University Students. Anat Sci. 2015;4:167-170.

33. Risley HH. The People of India, 2nd ed.; Crooke W., Ed., 1915; p. 20

34. Oladipo GS, Eroje MA, Fawehinmi HB. Anthropometric comparison of the nasal indices between the Adoni and Okrika ethnic groups of Rivers state, Nigeria. Int J Med Sci. 2009;1:135-137.

35. Oladipo G S, Oyakhire M O, Ugboma HAA. Anthropometric studies of nasal indices of the Ekpeye and Ikwerre ethnic groups in Nigeria. Asian J Med Sci. 2010;2:167-169.

36. Audu EB. An analytical view of temperature in Lokoja, Kogi state, Nigeria. Int J Sci Technol. 2012;2:856-859.

37. Sanusi YK, Abisoye SG, Faluyi OO. Estimation of temperature-humidity index in some selected locations in Nigeria. Res J Eng App Sci. 2013;2:70-73.

38. Franciscus RG, Long JC. Variation in human nasal height. Am J Phys Anthropol. 1991:85:419-427.

39. Zhang XT, Wang SK, Zhang W. Measurement and study of the nose and face and their correlations in the young adult of Han nationality. Plast Reconstr Surg. 1990;85:532-536.

40. Last RJ. Anatomy Applied and Regional, 6th ed.; Churchill Livingstone, 1981; pp. 398-403.

41. Hall RL, Hall DA. Geographic variation of native people along the Pacific Coast. Human Biol. 1981:67:407-426.

42. Farkas LG, Hreczko TA, Deutsch CK. Objective assessment of standard nostril types-A morphometric study. Ann Plast Surg. 1983:11:381-389.

43. Aung SC, Foo CL, Lee ST. Three dimensional laser scan assessment of the oriental nose with a new classification of oriental nasal types. Br J Plast Surg. 2000;53:109-116. 